\title{
Revealing performance factors for supply chain sustainability: a systematic literature review from a social capital perspective
}

\author{
Gustavo Picanço Dias ${ }^{1}$, Minelle E. Silva² \\ ${ }^{1}$ Federal University of Piaui - UFPI, Business Administration Department, Picos, PI, Brazil. \\ ${ }^{2}$ Supply Chain, Purchasing and Project Management Department, Excelia Business School - CERIIM research centre, La \\ Rochelle, France.
}

How to cite: Dias, G.P. and Silva, M.E. (2022), "Revealing performance factors for supply chain sustainability: a systematic literature review from a social capital perspective", Brazilian Journal of Operations \& Production Management, Vol. 19, No. 1, e20221170. https://doi.org/10.14488/BJOPM.2021.037

\begin{abstract}
Goal: The supply chain sustainability (SCS) literature is missing studies that specifically analyse factors that impact sustainability performance in supply chains, according to specific theoretical backgrounds. Within this context, this paper aims to understand how and why social capital theory (SCT) can inspire SCS studies and practice. In doing so, two research questions are addressed: (1) How has the SCS literature evolved in its application of the social capital theory?, and (2) What are the main sustainability performance factors studied in SCS?.
\end{abstract}

Design / Methodology / Approach: A systematic literature review was developed. Data were collected from 12 years (2008-2019) in two databases (i.e. EBSCO and Web of Science) and a total of 56 articles were selected and analysed through deductive and inductive content analysis.

Results: The analysis revealed 24 performance factors that influence SCS research throughout the three sustainability dimensions (i.e. economic, environmental and social). We found that social capital makes a significant conceptual contribution to understanding how the supply chain practices (i.e. cooperation, coordination, collaboration, resource exchanges and information sharing) explain how relationships are formed and interrelated to improve SCS performance.

Limitations of the investigation: The use of two databases may present limited results, which may have resulted in missing publications.

Practical implications: By recognising the performance factor for SCS, managers can identify their supply chain practices and increase their strategies within the relationship.

Originality / Value: By revealing the performance factors that can increase SCS, this paper reinforce how powerful SCT is to explain SCS performance.

Keywords: Supply Chain Sustainability; Social Capital Theory; Performance; Supply Chain Practices; Systematic Literature Review.

\section{INTRODUCTION}

Supply chain sustainability (SCS) studies have evolved in recent years (Silva et al., 2017), mainly emphasising the identification of what methods and initiatives has been developed by scholars and practitioners (Carter et al., 2019). However, much of the research is a-theoretical (cf. Touboulic and Walker, 2015b), omitting debates on the roots of certain theories and the

Financial support: We thank the National Council for Scientific and Technological Development (CNPq) for supporting our research under the Grant Number $n^{\circ}$ 426155/2018-1.

Conflict of interest: The authors have no conflict of interest to declare.

Corresponding author: gustavopicanco@ufpi.edu.br

Received: 18 Feb 2021.

Approved: 21 May 2021.

Editor: Julio Vieira Neto. 
consequences of applying them, for example, through social theories (Bastas and Liyanage, 2018; Govindan et al., 2020; Touboulic and Walker, 2015b). The lack of research on sustainability and supply chain management (SCM) that scans new avenues for advancing theories represents a gap in the literature on a topic in need of more attention. Thus, we believe that the depth of certain theories can help to spotlight underexplored or unknown issues related to supply chain practices and performance to help in developing a more comprehensive understanding of SCS.

To address this research gap, this paper studies how and why social capital theory (SCT) can inspire SCS studies. In doing so, we aim to identify further connections between SCT and SCS, since the current correlations are broad and generic (e.g. Gelderman et al., 2020; Kilubi and Rogers, 2018; Lu et al., 2018; Shin et al., 2019). Despite SCT has received increased attention in the SCM literature (Matthews and Marzec, 2011), it is limited in terms of SCS (Lu et al., 2018). The use of SCT is justified by its power to explain how social relations are established and how individual behaviours affect collective goals (Coleman, 1988; Granovetter, 1983; Putnam, 2000). Also, since SCT is rooted in relational norms such as trust, social norms, commitment and reciprocity, among others, and when applied to SCM, it can improve performance (Cai et al., 2011; Gelderman et al., 2016; Krause et al., 2007; Lawson et al., 2008; Moran, 2005; Roden and Lawson, 2014), reduce risks (Kilubi and Rogers, 2018) and promote innovation (Carey et al., 2011). However, the literature for SCM has a strong emphasis on the buyer-supplier relationship (BSR) (Gelderman et al., 2016; Matthews and Marzec, 2011; Tsai and Ghoshal, 1998), which limits a deep comprehension of the supply chain.

The first study to examine the use of social capital in operations management was completed by Nahapiet and Ghoshal (1998), who claimed that social capital is formed through three dimensions: structural, cognitive and relational capital. Structural capital is represented by networks, and cognitive capital is represented by shared codes, language and narratives; relational capital is formed through trust, social norms and commitment (Nahapiet and Ghoshal, 1998; Tsai and Ghoshal, 1998). However, it is known that few studies examine all three dimensions of the SCT (e.g. Gölgeci et al., 2019; Kilubi and Rogers, 2018; Shin et al., 2019), which ratifies the relevance of developing a review of how publications in the last decade. Most studies existing in the literature focus on variations of one or two of the SCT dimensions to understand SCM, which affects the understanding of how sustainability performance is supported by relationships. Thus, since application of the SCT in SCS studies has been limited (Touboulic and Walker, 2015b) and it represents a great opportunity to understand SCS performance, we aim to answer two questions:

RQ 1: How has the SCS literature evolved in its application of the social capital theory?

RQ 2: What are the main sustainability performance factors studied in SCS?

To address these questions, a systematic literature review of publications from 2008 through 2019 was conducted. We justify this period based on Seuring and Müller's (2008) and Carter and Rogers's (2008) publication, which expanded SCM studies to incorporate sustainability issues. Similar to Fritz and Silva (2018), we use the term SCS instead of sustainable SCM, because currently sustainability is not truly observed in supply chains (Pagell and Shevchenko, 2014). It is not possible to claim anything as sustainable when it merely represents a journey to achieve sustainability. This paper is characterised as theory building (Seuring et al., 2020); for that reason, we merged SCM and SCS studies in our analysis to improve our knowledge on these topics. In addition, although we analyse sustainability via the Triple Bottom Line (TBL) (Elkington, 2002), we understand that such a framework is not sufficient for explaining all contexts equally (Elkington, 2018; Fritz and Silva, 2018). Thus, we understand sustainability not as an end in itself but as a set of practices performed over time (Silva and Figueiredo, 2020).

Through a new interpretation of current publications, this paper improve existing connections surrounding SCS performance to create a bridge which shows SCT as a mechanism that may be used by practitioners and scholars to promote sustainability performance in supply chains. Thus, our contributions are not limited to the literature, but 
also includes new insights to managers regarding SCS performance. At the same time, we highlight that an assessment of performance cannot be limited to indicators or outcomes. We also demystify limiting the use of the SCT to study social sustainability only (cf. Ashby et al., 2012; Silva and Nascimento, 2015), since it should contribute to sustainability performance as a whole. Thus, this paper adds a new step (cf. Touboulic and Walker, 2015b) in understanding SCS theory and practice via the SCT.

\section{METHOD}

In order to address the research questions and better understand how and why the SCT can be used as a mechanism to improve SCS theory and practice, we employed the structured literature review method. The literature review may be used to map, consolidate and develop theory (Seuring and Gold, 2012), which implies a detailed description aimed at reducing bias and increasing transparency (Tranfield et al., 2003). Similar to others (e.g. Carter et al., 2019; Santos and Campos, 2021; Seuring and Müller, 2008), our systematic review does not analyse the entire body of the related literature but instead presents an informative and focused evaluation based on our research questions (Touboulic and Walker, 2015b). To this end, we followed Fink's (2014) seven-step structure to create systematic, explicit and reproducible results for the field. It is important to highlight that we use the literature review as a way to build theory on SCS, i.e. we are not limited to the review outcomes but provide further analysis (Seuring et al., 2020)

To begin the study, we reviewed the literature in order to identify the main research gaps and to select the research question(s) (Step 1). In sequence, Step 2 involves selecting the bibliographic or article databases. For this paper, we used two main databases: EBSCO (including Academic Search Premier and Business Source Elite) and Web of Science. In Step 3 we defined the research terms, and in Step 4 we applied practical screening criteria (explained in more detail in subsequent sections). We did not complete Step 5 because we did not have restrictions concerning the methodological screening criteria. To implement Step 6, we performed the content analysis of the selected papers, and we completed the final step, Step 7 , by synthesising the results using both qualitative and quantitative approaches. By following these steps, we ensured that the method was appropriately implemented.

\section{Research boundaries}

The research boundaries were defined to guide the literature review (Steps 3 and 4 of Fink's [2014] method) and design the next steps of the research. The first action was to delimit the keywords used to research only scientific papers published in the fields of sustainability and SCM. The keyword combinations used were 1) sustainab* AND supply chain, and 2) social capital AND supply chain. The use of these broad combinations allowed us to advance deeply on development of the research questions. Our research revealed that papers focused on social capital in supply chain with a sustainability emphasis were limited, so it was counterproductive to draw clear boundaries among sustainability dimensions; thus, we maintained our focus on SCM and understanding its impact for SCS studies. Consequently, during the research process we uncovered various issues related to green SCM: CSR in SCM, humanitarian SCM and SCS. Following this strategy, we achieved greater success in designing our systematic literature review. This process was developed by both researchers, following the recommendation of Tranfield et al. (2003).

Data for this research were gathered from a 12-year period (2008-2019), using the year of Seuring and Müller's (2008) and Carter and Rogers's (2008) publication as a kick-off date. In order to control quality, we selected only peer-reviewed papers (Burgess et al., 2006) published in English, which generated 107 papers (34 from EBSCO and 73 from Web of Science). As noted, only a few papers (specifically, 8) were fully related to sustainability, so papers related to SCM were considered as part of our sample of 107 papers. Details on each paper were saved in a shared Excel file. After applying the first criterion for exclusion, which was duplication, 65 papers remained. The second criterion for exclusion was that only articles 
from journals that were represented by two or more papers were included; applying this criterion excluded an additional seven papers. Through the review of all papers (Step 4), we excluded another six papers that applied the SCT as a secondary perspective (i.e. just as background) or mentioned it only in recommendations for future research. However, during the review process, we noted during the papers' analysis that four additional papers were important for their relevance to our research and, therefore, should be included in our sample. Although relevant papers may be missed using these defined criteria (Touboulic and Walker, 2015b), this did not invalidate our research. Our final database contained 56 papers (see Appendix).

\section{Content analysis}

A content analysis was performed to examine the 56 papers (Seuring and Gold, 2012). This technique may be used for quantitative and qualitative analyses of a large body of documents (e.g. scientific papers and interview transcriptions) (Mayring, 2000). We combined a deductive and an inductive approach for the content analysis, since we focused not only on classifying the selected papers but also on highlighting connections that may explain how and why the SCT can inspire SCS studies. For the deductive analysis we used three methods of classification. First, to classify sustainability, we used the TBL to establish social, economic and environmental categories for sustainability. In addition, similar to Fritz and Silva (2018), we used the term "mix" (for more than one dimension) and TBL+ (for papers that took a broader approach to sustainability). Second, to create categories for social capital, we used the three existing dimensions, namely, structural, cognitive and relational capital (Tsai and Ghoshal, 1998). Finally, to classify social capital practices, we used terms often mentioned in the literature, such as information sharing and collaboration. In addition, to map research methods, we followed the classification of Seuring and Müller (2008). For instance, to reveal the roots of the SCT, it was necessary to understand the contextualisation of each paper and create connections to design a new interpretation of several issues. The inductive analysis was relevant to show that the SCT may be considered a mechanism for fostering sustainability in supply chains. To develop the analysis, we used codes (see Appendix).

\section{Rigour of the research process}

Motivated to demonstrate rigour during our research process (Step 7), we used several strategies to ensure the reliability of our research (Burgess et al., 2006). First, following Seuring and Gold's (2012) recommendation, in order to ensure transparency and replicability of the research design, we carefully documented the entire process. In addition, similar to what other researchers have done (e.g. Touboulic and Walker, 2015b), we carried out several rounds of analysis via the double-check approach (Seuring and Gold, 2012) to reduce bias during the deductive and inductive phase. Validity was established by comparing the results with an internal analysis of the database, which ensured that we were analysing the correct data.

\section{RESULTS}

This section presents answers to the two research questions. First, we show how the application of the SCT into SCS studies evolved following a descriptive analysis. Second, we highlight sustainability performance factors identified.

\section{Descriptive features of publications}

The analysis of the 56 papers in our database explained in the following section shows the main characteristics of the SCM articles documenting research in which the SCT was applied. Because we considered all publications under the sustainability lens, the economic focus for our research is represented by traditional SCM studies. The following information was compiled to elucidate the range of publications we analysed: number of publications per year, list of journals, industry sectors represented and research methods applied. Using these 
main classifications, it was possible to create a picture of the publications from the 12-year study period.

\section{RQ 1: How has the SCS literature evolved in its application of the social capital theory?}

Number of publications per year. The number of publications using the SCT has been increasing since 2008 (Figure 1), although the studies documented have not exclusively focused on sustainability, a finding similar to that of Touboulic and Walker (2015b). We can see from the illustration in Figure 1 that a boom in publications occurred during the last six years, during which almost triple the number of publications from the initial six years under analysis were identified. This result may be due to the call for more research using social theories in SCM literature (Ashby et al., 2012) but may also be because of the growing search by scholars for a better understanding of inter-organisational collaboration in SCM (Min et al., 2019).

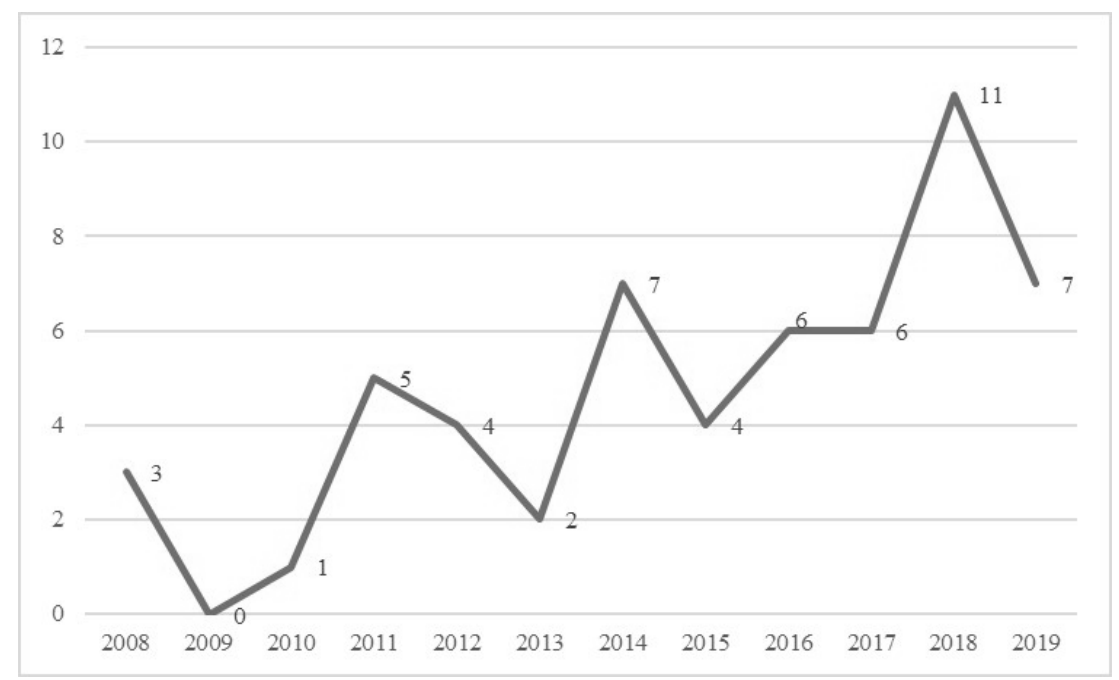

Figure 1: Number of papers per year $(\mathrm{N}=56)$. Source: Research data (2020)

Journals. A number of the selected papers were published in one of six operations management journals, with the number of articles from each journal ranging from four to eight: Supply Chain Management: An International Journal (8), International Journal of Production Economics (7), Journal of Supply Chain Management (5), International Journal of Operations and Production Management (4), Journal of Business Logistics (4) and Journal of Purchasing and Supply Management (4). From a broader perspective, these six journals collectively contain more than $50 \%$ of the publications related to the SCT and SCS identified for this study, which verifies interest in the SCT in the operations management field. The remaining selected papers were published in 10 other journals, including Journal of Operations Management (3) and Journal of Cleaner Production (3); each of the 10 journals contained either 2 or 3 of the selected papers. As we can see the use of SCT in operations management present a seasonality per year; however, there is an upward tendency in the last years under analysis.

Industry sectors. No clear preference for industry sector was represented by the selected studies, since they were primarily developed in multi-industries (30 out of 56). This broad perspective is related to the research methods used for those studies. Studies developed in singular industries focused more on the automotive ( 3 out of 56) and electronics ( 3 out of 56) industries. The other publications are spread across seven industries (e.g. textile, construction and transportation). These findings are similar to those of SCS studies that do not focus on a specific theory (e.g. Carter et al., 2019), which often involve multi-industries.

Research method. To analyse this category, initially we used the classification of Seuring and Müller (2008): conceptual paper (theory), case studies (case), surveys, modelling papers (model) and literature reviews (review). However, during the analysis we discovered the need 
to add an additional method: grounded theory. The data reflected a predominance of surveys (see Table 1) used in the study of the SCT in SCS. This finding reinforces the existence of studies that only analyse direct relationships between the SCT and SCM, which was noted by Nahapiet and Ghoshal (1998) and Tsai and Ghoshal (1998). Based on these studies, the better method for examining how practices are built from social capital or how social capital works with such practices to improve SCM performance is cause and effect analysis.

Table 1: Research methodologies used in the papers $(N=56)$

\begin{tabular}{ccc}
\hline Research method & List of papers & Total \\
\hline Surveys & $2,4,5,8,9,10,12,13,14,16,17,18,21,23,24,25,26,27$, & 34 \\
& $28,28,32,33,34,35,38,39,40,43,48,49,50,51,52,54,55$ & \\
\hline Models & $19,20,22,30,31,37$ & 6 \\
\hline Cases & $3,15,41,46,47,53$ & 6 \\
\hline Review & $11,36,42,56$ & 4 \\
\hline Theory & $1,6,7,44,45$ & 5 \\
Grounded theory & 29 & 1 \\
\hline
\end{tabular}

Source: Research data (2020)

It is evident that the use of more qualitative methods in further studies may support scholars in their efforts to discern a relationship between how SCM practices and performance differ from each other and how they manifest in the same level of practice. With another method it is possible, for instance, to understand trust and commitment from a deeper perspective, since analyses of such factors are not limited to a choice between exist or not, influence or not. There is a need for more critical analysis, which does not depend on the method used but on the ambitions behind the research questions. Since we understand that sustainability creates a complex environment in its application, the use of more qualitative research and mixed methods research can increase the depth of studies on the application of the SCT in SCS. It is also noteworthy that the number of conceptual analyses was minimal (5 out of 56); this approach may deserve more attention in order to identify solid connections among several research themes. Since Nahapiet and Ghoshal (1998), SCT is presented as a powerful theory for improving organisational performance. From this study, the use of SCT was widely through the predominance of direct correlations by surveys and modelling. In doing this, the relationship between SCT and operations literature shows little progress in inserting new applicability and deepening the origins of social capital and how relationships between individuals can provide better-operating results.

\section{Sustainability performance analysis}

To understand performance it is necessary to reveal the unit of analysis used in the selected papers. We found that studies concentrated on the focal firm ( 25 out of 56 ) and dyadic relationship (21 out of 56) represented the majority of the research (i.e. 46 out of 56). This result corroborates with the findings of Gelderman et al. (2016) and Matthews and Marzec (2011) about the need to extend supply chain connections to study the SCT. More recently, the triadic relationship was approached in examining the relationship between the SCT and SCM (e.g. Papers 51 and 56); however, this relationship is underexplored. This result shows that a new approach needs to be taken when investigating the relationship between the SCT and SCS. We agree that a broader view of the supply chain could better explain the relationship and how supply chain practices among stakeholders can improve performance. Moreover, a restricted analysis of the supply chain can hide the weakest link in a broader supply chain. Therefore, we consider this a gap in the use of the SCT to understand supply chain relationships.

As observed in several systematic literature reviews (e.g. Ashby et al., 2012; Carter et al., 2019; Seuring and Müller, 2008; Silva et al., 2017; Touboulic and Walker, 2015b), there is a 
trend of analysing sustainability through only the environmental and social dimensions, even though the TBL is the frame selected for discussion. For this paper we intended to use a broad approach to the TBL+ (Fritz and Silva, 2018); however, after observing that the papers selected did not place emphasis on sustainability, we realised it was not possible to apply that additional lens in general. Therefore, we decided to conduct a detailed examination of the economic dimension through the traditional SCM research stream to uncover how the SCT can be connected to SCS. Thus, we focused at this point on the following research question:

\section{RQ 2: What are the main sustainability performance factors studied in SCS?}

Through our analysis we found that 27 papers clearly identified factors that may be connected to sustainability performance. Table 2 summarises these main factors. As indicated in Table 2, these factors are centred in the TBL dimensions and can be used to understand the connections between SCT practices and performances. Few examples addressed sustainability as a whole in their research. For example, Paper 42 claimed that social networks, which are connected to structural capital, have a direct link to sustainability performance. In general, use of the SCT is directly related to a business's operational and strategic performance (Gelderman et al., 2016), which we also found through our analysis. Thus, we understand that economic sustainability performance is represented by operational, financial and strategic performance.

Table 2: Sustainability performance factors presented in the papers having such factors ( $N=27$ papers)

\begin{tabular}{|c|c|c|}
\hline Factors & List of papers & Total \\
\hline \multicolumn{3}{|c|}{ Economic performance } \\
\hline Quality & \multirow{11}{*}{$\begin{array}{c}2,3,4,5,8,9,12,13,14,15,18,19,20,21 \\
24,25,26\end{array}$} & \multirow{11}{*}{17} \\
\hline Lead time & & \\
\hline Delivery & & \\
\hline Product/Process Design & & \\
\hline Turnover (profit) & & \\
\hline Technology & & \\
\hline Flexibility & & \\
\hline Visibility & & \\
\hline Reliability & & \\
\hline Innovation & & \\
\hline Market share & & \\
\hline \multicolumn{3}{|c|}{ Environmental Performance } \\
\hline Eco design & \multirow{9}{*}{$10,17,22,23,26,27,37$} & \multirow{9}{*}{7} \\
\hline Green purchasing & & \\
\hline Sustainable procurement & & \\
\hline Green innovation & & \\
\hline Pollution reduction & & \\
\hline Waste reduction & & \\
\hline Low consumption of raw material & & \\
\hline Low consumption of energy & & \\
\hline Environmentally friendly products & & \\
\hline \multicolumn{3}{|c|}{ Social Performance } \\
\hline Human rights & \multirow{4}{*}{$42,50,51$} & \multirow{4}{*}{3} \\
\hline Corporate social responsibility & & \\
\hline Rewards & & \\
\hline Social satisfaction & & \\
\hline
\end{tabular}

Source: Research data (2020)

In addition to these performance factors, some papers had a different focus. Therefore, following the analysis by dimensions, as mentioned previously, the main emphasis was on traditional SCM research, which was used for the economic sustainability dimension in our 
analysis. A total of 39 papers (out of 56) were found with that focus. The environmental sustainability dimension was the second most frequently observed focus ( 5 out of 56 ) and, per consequence, the social sustainability dimension was last (4 out of 56 ). We found six papers classified as having a mixed dimension focus, since they used two different dimensions in their analyses, maintaining the connection with the economic dimension (i.e. economic and social or economic and environmental). We did not find any papers in which the environmental and social dimensions were combined. Finally, only two (Papers 42 and 56) were classified as TBL, since they presented the three dimensions in the same study. Paper 42 contains a clear debate about cultural issues in the Chinese dynamic, but it did not use the broader perspective necessary to be classified as TBL+. In some cases "sustainability and environment have been used interchangeably" (Carter and Liane Easton, 2011, p. 54). Even so, the use of the SCT in SCS is less explored in the literature. This result shows the opportunity for future research in using the SCT to understand SCS. In this context, it is necessary to observe that mathematical modelling studies may have difficulties in well linking the three SCT dimensions and multiple sustainability dimensions, which can be addressed by future studies relating both approaches.

\section{Bridging connection towards SCS through social capital}

To understand how and why the SCT is related to SCS studies, the analysis as explained thus far demonstrated an overview of published papers and provided insights about what factors can be used to increase studies on this theory. However, it is also necessary to extract details on the theory from the selected publications. To this end we needed first to consider the main dimensions used to study the SCT, since, according Matthews and Marzec (2011), and Lee and $\mathrm{Ha}$ (2018), few studies can be found in the literature that consider all three aspects of the SCT. However, as can be observed in Figure 2, we found that, in reality, the three dimensions were addressed in the majority of the research documented in the papers, which provides a new perspective on the topic. Analysis of the three dimensions enables the identification of a link among structural, cognitive and relational capital.

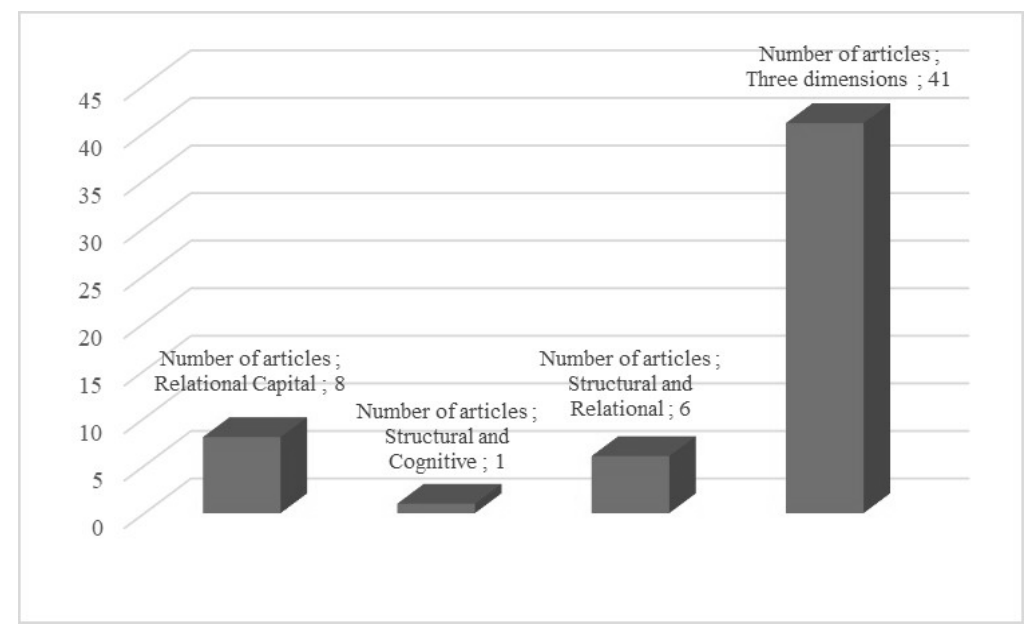

Figure 2: Number of paper per dimension $(\mathrm{N}=56)$. Source: Research data (2020)

Although the primary focus of the papers was on all three SCT dimensions, these dimensions were considered separately, with a linear relationship between them. That created an opportunity to rethink the research on the SCT, since, according to Hughes and Perrons (2011, p. 170), "social capital does not develop linearly as portrayed in prior investigations in this area, but is instead formed through a series of complex interactions among the three dimensions of social capital". That perspective does not permit a general valuation of SCT as a social system comprising relationships and networks (Granovetter, 1985); rather, it perceives social capital resulting from interactions between structural, cognitive and relational capital. 
Therefore, emphasis on one SCT dimension can be skewed in a study and its orientation to understand social relations.

For instance, trust and social norms are essential lubricants of any social system (Coleman, 1990; Granovetter, 2000; Putnam, 2000). Thus, without trust and compliance with social norms, it is not possible to establish social ties, much less share information, language and narratives with others. Furthermore, the papers reflect the misunderstanding that relational capital represents the most relevant aspect of the SCT literature. In the literature, we found that relational capital can be used as a general concept for social capital, when the relationships are structured by trust and commitment (e.g. Papers 7, 12 and 19) or by Guanxi in interpersonal definitions on Chinese culture (e.g. Papers 13 and 48). The Guanxi involves interpersonal relationships (Paper 50), and it is perceived as social capital (Papers 39 and 50). Other combinations of the SCT are also pointed out in the research, specifically, the structural and cognitive dimensions and the structural and relational dimensions.

In addition to understanding the SCT dimensions, it is necessary to understand their relationship to performance. The literature is assertive in claiming that the encouragement of social capital improves management practices that support supply chain performance (Lin, 2001; Min et al., 2008; Carey et al., 2011; Awais et al., 2018; Fan and Stevenson, 2018; Roy et al., 2018; Shin et al., 2019). Some practices are often used to analyse the SCT (see Table 3); however, other elements can also be mentioned in order to understand social capital as a whole. Every practice impacts the SCM differently, mainly when analysing their connection to the SCT dimensions. Under this discussion, we found collaboration as the main practice used to support SCM performance to date.

Table 3: SCT practices studied in the papers ( $N=39$ as opposed to 56$)$

\begin{tabular}{ccc}
\hline Practices & List of papers & Total \\
\hline Collaboration & $5,13,15,22,24,26,27,28,35,38,39,44,47,48,51,52,53$ & 17 \\
\hline Information sharing & $10,18,21,27,30,31,40,43,50,54,56$ & 11 \\
\hline Resource exchange & $2,4,9,12,33,34,40,41,46,55,56$ & 11 \\
\hline Cooperation & $7,9,10,19,33$ & 5 \\
\hline Commitment & 23,52 & 2 \\
\hline
\end{tabular}

Source: Research data (2020)

Aware of this information from current publications on the SCT in the SCM literature, it is necessary to discuss next steps. We believe that strengthening sustainability based not only on performance but also on practices can increase the success of supply chains in different sectors. In this context, we understand practice as a set of activities and/or initiatives that interact with each other through an ongoing process of intra- and inter-organisational performance to help managers in making decisions (Bromiley and Rau, 2014; Silva and Figueiredo, 2020). The literature shows a clear connection between SCT dimensions and supply chain practices. However, there are some limitations to observe how social capital elements such as trust, reciprocity, commitment, social rules, communication, and networks can improve the supply chain practices to SCS performance. The majorities of papers limit the relationship between SCT and SCS to the dimensional level of social capital. Thus, further studies need to be developed in order to better recognise practice beyond the traditional performance focus.

\section{CONCLUSIONS AND FURTHER RESEARCH}

By bridging connections between SCT and SCS this paper have multiple contributions to the literature. First, relationships among supply chain members present robust tools for improving SCS. SCT elements such as sharing of codes, languages and narratives, trust, reciprocity and networks have strong connections with supply chain practices (i.e. 
cooperation, collaboration, information sharing and resource exchange) and deserve further attention by scholars. The relationship between SCT and supply chain practices yet is presented through correlations among factors, and little is now known about how the social capital elements could develop best supply chain practices (e.g. Gelderman et al., 2020; Kilubi and Rogers, 2018; Lu et al., 2018; Shin et al., 2019). In other words, further studies need to go beyond a limited focus on performance issues to introduce also a practice approach that can reveal hidden SCT elements.

Second, although less explored (e.g. Lu et al., 2018), the analysis of the SCT and SCS should assume all dimensions for both TBL+ (i.e. economic, environment, social, cultural and institutional) and SCT (i.e. relational, cognitive and structural). In doing so, new insights may emerge to better explain SCS practice and performance. The SCT involves critical elements that need to be considered in the individual relationships to develop supply chain practices and sustainability performance. The relationship between SCT and SCS involves dimensions that interrelate among them that are not observed only through relation cause and effect. For majorities of the papers, the relationship between SCT and operations literature only shows the importance of the social relationships to improve practices and operational performance (cf. Azevedo et al., 2018; Dania et al., 2018; Min et al., 2005; Touboulic and Walker, 2015a; Villena et al., 2011).

Third, this paper shows that the deepening of social relationships could represent an important instrument for developing SCS performance. Moreover, for the development of sustainability widely, it needs to get to know the relationship among supply chain members beyond the buyer-supplier relationship (e.g. Gelderman et al., 2016; Matthews and Marzec, 2011; Tsai and Ghoshal, 1998) once the restricted view between supply chain members can not represent sustainability in all their extension. In this paper it was shown that SCS practices are built deliberately, not randomly, through social values formed from relationships between individuals and companies, which is aligned with the findings of Silva and Figueiredo (2020). Therefore, studies need to change their unit of analysis from BSR to supply chain and network approaches.

Finally, since coordination, cooperation, collaboration, information sharing and resource exchanges are practices that rely on relationships among supply chain members in order to occur, the study of social capital and its features is essential to comprehend how the relationships arise and how we can improve these practices in the supply chain. Thus, the SCT presents itself as a theory that goes beyond social development. This theory also represents a way for economic and environmental performance and their development to contribute to continuous improvement of SCS. Establishing sustainability through the SCT permits an execution beyond regimental compromise or efforts designed merely to meet internal and external requirements; the social view enables a better comprehension of sustainability in an extended and multi-tiered supply chain.

As a managerial contribution, this paper shows that by recognising the revealed SCS performance factors according to SCT, it is possible to correct organisational failures and existing misunderstandings among supply chain members. Thus, managers can improve their supply chain practices and SCS outcomes by thinking about new methods and strategies for SCM. In addition, the 24 performance factors presented in Table 2 shows the need to further emphasis on the social sustainability for SCS. More than focusing on human rights, corporate social responsibility, rewards, and social satisfaction, it is necessary to think about new factors that really represent the connection with SCT. For example, trust could emerge as a factor when developing further strategies and managing operations. Other factors can be also considered, which includes cultural (e.g. local traditions) and institutional (e.g. stakeholder engagement) elements.

Some limitations were identified in this research. The first refers to the overlook of leadership practices and the empowerment of supply chain members. This lack does not deny the credibility and reliability of the data gathered, but emerge as a source for new studies. In this way, future research can consider the inclusion of these elements and improve qualitative research that relates the SCT and SCS. Also as limitations of this research, we can consider the 
focus on only two databases, which may have resulted in missing publications. Another limitation of this paper is the optimistic view of social capital and its benefits; however, it is possible that a relationship based on strong trust can also give rise to conflict and enable opportunistic behaviours on the part of individuals. Future research should explore the social capital from deepening the origins of the social relationships and examine the dark side of social capital between the SCT and SCS. The breadth of the social capital allows for integrations and future links with the process of forming the organizational culture (Ludolf et al., 2017) and the process of democratizing organizational relations.

\section{REFERENCES}

Ashby, A., Leat, M. and Hudson-Smith, M. (2012), "Making connections: a review of supply chain management and sustainability literature", Supply Chain Management, Vol. 17, No. 5, pp. 497-516. http://dx.doi.org/10.1108/13598541211258573.

Awais, S., Tipu, A. and Fantazy, K. (2018), "Exploring the relationships of strategic entrepreneurship and social capital to sustainable supply chain management and organizational performance", International Journal of Productivity and Performance Management, Vol. 97, No. 9, pp. 2046-70.

Azevedo, S.G., Silva, M.E., Matias, J.C.O. et al. (2018), "The Influence of Collaboration Initiatives on the Sustainability of the Cashew Supply Chain", Sustainability, Vol. 10, No. 6, pp. 2075. http://dx.doi.org/10.3390/su10062075.

Bastas, A. and Liyanage, K. (2018), "Sustainable supply chain quality management: a systematic review", Journal of Cleaner Production, Vol. 181, pp. 726-44. http://dx.doi.org/10.1016/j.jclepro.2018.01.110.

Bromiley, P. and Rau, D. (2014), "Towards a practice-based view of strategy", Strategic Management Journal, Vol. 35, No. 8, pp. 1249-56. http://dx.doi.org/10.1002/smj.2238.

Burgess, K., Singh, P.J. and Koroglu, R. (2006), "Supply chain management: a structured literature review and implications for future research", International Journal of Operations \& Production Management, Vol. 26, No. 7, pp. 703-29. http://dx.doi.org/10.1108/01443570610672202.

Cai, S., Yang, Z. and Jun, M. (2011), "Cooperative norms, structural mechanisms, and supplier performance: Empirical evidence from Chinese manufacturers", Journal of Purchasing and Supply Management, Vol. 17, No. 1, pp. 1-10. http://dx.doi.org/10.1016/j.pursup.2009.12.006.

Carey, S., Lawson, B. and Krause, D.R. (2011), "Social capital configuration, legal bonds and performance in buyer-supplier relationships", Journal of Operations Management, Vol. 29, No. 4, pp. 277-88. http://dx.doi.org/10.1016/j.jom.2010.08.003.

Carter, C.R. and Liane Easton, P. (2011), "Sustainable supply chain management: evolution and future directions", International Journal of Physical Distribution \& Logistics Management, Vol. 41, No. 1, pp. 46 62. http://dx.doi.org/10.1108/09600031111101420.

Carter, C.R. and Rogers, D.S. (2008), "A framework of sustainable supply chain management: moving toward new theory", International Journal of Physical Distribution \& Logistics Management, Vol. 38, No. 5, pp. 360-87. http://dx.doi.org/10.1108/09600030810882816.

Carter, C.R., Hatton, M.R., Wu, C. et al. (2019), "Sustainable supply chain management: continuing evolution and future directions", International Journal of Physical Distribution \& Logistics Management, Vol. 50, No. 1, pp. 122-46. http://dx.doi.org/10.1108/IJPDLM-02-2019-0056.

Coleman, J.S. (1988), "Social capital in the creation of human capital", American Journal of Sociology, Vol. 94, pp. S95-120. http://dx.doi.org/10.1086/228943.

Coleman, J.S. (1990), "Foundations of social theory", Foundations of Social Theory, Vol. 69, No. 2, pp. 993. http://dx.doi.org/10.2307/2579680.

Dania, W., Xing, K. and Amer, Y. (2018), "Collaboration behavioural factors for sustainable agri-food supply chains: a systematic review", Journal of Cleaner Production, Vol. 186, pp. 851-64. http://dx.doi.org/10.1016/j.jclepro.2018.03.148.

Elkington, J. (2002), Cannibals with Forks: The Triple Botton Line of 21st Century Business, Capstone, Oxford.

Elkington, J. (2018). "25 years ago I coined the phrase "Triple Bottom Line": here's why it's time to rethink it", Harvard Business Review, 25 June 2018. 
Fan, Y. and Stevenson, M. (2018), "Reading on and between the lines : risk identification in collaborative and adversarial buyer - supplier relationships", Supply Chain Management, Vol. 23, No. 4, pp. 351-76. http://dx.doi.org/10.1108/SCM-04-2017-0144.

Fink, A. (2014). Conducting Research Literature Reviews: from the Internet to Paper, 4th ed., Sage, Thousand Oaks, CA.

Fritz, M.M.C. and Silva, M.E. (2018), "Exploring supply chain sustainability research in Latin America", International Journal of Physical Distribution \& Logistics Management, Vol. 48, No. 8, pp. 818-41. http://dx.doi.org/10.1108/IJPDLM-01-2017-0023.

Gelderman, C.J., Semeijn, J. and Mertschuweit, P.P. (2016), "The impact of social capital and technological uncertainty on strategic performance: The supplier perspective", Journal of Purchasing and Supply Management, Vol. 22, No. 3, pp. 225-34. http://dx.doi.org/10.1016/j.pursup.2016.05.004.

Gelderman, C.J., Semeijn, J., Ter Avest, F. et al. (2020), "Social capital, power and information sharing: evidence from the Dutch meat processing industry", British Food Journal, Vol. 122, No. 11, pp. 334360. http://dx.doi.org/10.1108/BFJ-08-2019-0607.

Gölgeci, I., Gligor, D.M., Tatoglu, E. et al. (2019), "A relational view of environmental performance: what role do environmental collaboration and cross-functional alignment play", Journal of Business Research, Vol. 96, pp. 35-46. http://dx.doi.org/10.1016/j.jbusres.2018.10.058.

Govindan, K., Rajeev, A., Padhi, S.S. et al. (2020), "Supply chain sustainability and performance of firms : A meta- analysis of the literature", Transportation Research Part E, Logistics and Transportation Review, Vol. 137, pp. 101923. http://dx.doi.org/10.1016/j.tre.2020.101923.

Granovetter, M. (1983), "The strength of weak ties: a network theory revisited", American Sociological Association, Vol. 1, pp. 201-33. http://dx.doi.org/10.2307/202051.

Granovetter, M. (1985), "Economic action and social structure: the problem of embeddedness", American Journal of Sociology, Vol. 91, No. 3, pp. 481-510. http://dx.doi.org/10.1086/228311.

Granovetter, M. (2000), "A theoretical agenda for economic sociology", in Guillen, M.F., Collins, R., England, P. and Meyer, M. (Eds.), The New Economic Sociology: Developments in an Emerging Field, Russell Sage Foundation, pp. 1-30.

Hughes, M. and Perrons, R.K. (2011), "Shaping and re-shaping social capital in buyer - supplier relationships", Journal of Business Research, Vol. 64, No. 2, pp. 164-71. http://dx.doi.org/10.1016/j.jbusres.2009.12.009.

Kilubi, I. and Rogers, H. (2018), "Bridging the gap between supply chain risk management and strategic technology partnering capabilities: insights from social capital theory", Supply Chain Management, Vol. 23, No. 4, pp. 351-76. http://dx.doi.org/10.1108/SCM-02-2017-0091.

Krause, D.R., Handfield, R.B. and Tyler, B.B. (2007), "The relationships between supplier development, commitment, social capital accumulation and performance improvement", Journal of Operations Management, Vol. 25, No. 2, pp. 528-45. http://dx.doi.org/10.1016/j.jom.2006.05.007.

Lawson, B., Tyler, B.B. and Cousins, P.D. (2008), "Antecedents and consequences of social capital on buyer performance improvement", Journal of Operations Management, Vol. 26, No. 3, pp. 446-60. http://dx.doi.org/10.1016/j.jom.2007.10.001.

Lee, C.-H. and Ha, B.-C. (2018), "The impact of buyer-supplier relationships' social capital on bi- directional information sharing in the supply chain", Journal of Business and Industrial Marketing, Vol. 33, No. 3, pp. 325-36. http://dx.doi.org/10.1108/JBIM-01-2017-0021.

Lin, N. (2001), Social Capital: a Theory of Social Structure and Action, Cambridge University Press, Cambridge. http://dx.doi.org/10.1017/CBO9780511815447.

Lu, H.E., Potter, A., Sanchez Rodrigues, V. et al. (2018), "Exploring sustainable supply chain management: a social network perspective", Supply Chain Management, Vol. 23, No. 4, pp. 522-41. http://dx.doi.org/10.1108/SCM-11-2016-0408.

Ludolf, N.V.-E., Silva, M., Gomes, C.F.S. et al. (2017), "The organizational culture and values alignment management importance for successful business", Brazilian Journal of Operations \& Production Management, Vol. 14, No. 2, pp. 272. http://dx.doi.org/10.14488/BJOPM.2017.v14.n2.a15.

Matthews, R.L. and Marzec, P.E. (2011), "Social capital, a theory for operations management: a systematic review of the evidence", International Journal of Production Research, Vol. 50, No. 24, pp. 7081-99. http://dx.doi.org/10.1080/00207543.2011.617395. 
Mayring, P. (2000). Qualitative Inhaltsanalyse: Grundlagen und Techniken, 7th ed., Deuscher Studien Verlag, Weinheim.

Min, S., Kim, S.K. and Chen, H. (2008), "Developing social identity and social capital for supply chain management", Journal of Business Logistics, Vol. 29, No. 1, pp. 283-304. http://dx.doi.org/10.1002/j.2158-1592.2008.tb00079.x.

Min, S., Roath, A.S., Daugherty, P.J. et al. (2005), "Supply chain collaboration: what's happening", International Journal of Logistics Management, Vol. 16, No. 2, pp. 237-56. http://dx.doi.org/10.1108/09574090510634539.

Min, S., Zacharia, Z.G. and Smith, C.D. (2019), "Defining supply chain management: in the past, present, and future", Journal of Business Logistics, Vol. 40, No. 1, pp. 44-55. http://dx.doi.org/10.1111/jbl.12201.

Moran, P. (2005), "Structural vs. relational embeddedness: social capital and managerial performance", Strategic Management Journal, Vol. 26, No. 12, pp. 1129-51. http://dx.doi.org/10.1002/smj.486.

Nahapiet, J. and Ghoshal, S. (1998), "Social capital, intellectual capital, and the organizational advantage", Academy of Management Review, Vol. 23, No. 2, pp. 242-66. http://dx.doi.org/10.5465/amr.1998.533225.

Pagell, M. and Shevchenko, A. (2014), "Why research in sustainable supply chain management should have no future", The Journal of Supply Chain Management, Vol. 50, No. 1, pp. 44-55. http://dx.doi.org/10.1111/jscm.12037.

Putnam, R. (2000). Bowling Alone: the Collapse and Revival of American Community, Vol. 1, Simon \& Schuster, New York.

Roden, S. and Lawson, B. (2014), "Developing social capital in buyer-supplier relationships: The contingent effect of relationship-specific adaptations", International Journal of Production Economics, Vol. 151, pp. 89-99. http://dx.doi.org/10.1016/j.ijpe.2014.01.008.

Roy, V., Schoenherr, T. and Charan, P. (2018), "The thematic landscape of literature in sustainable supply chain management (SSCM)", International Journal of Operations \& Production Management, Vol. 34, No. 4, pp. 1091-124. http://dx.doi.org/10.1108/IJOPM-05-2017-0260.

Santos, P.S. and Campos, L.M.S. (2021), "Practices for garment industry's post-consumer textile waste management in the circular economy context: an analysis on literature", Brazilian Journal of Operations \& Production Management, Vol. 18, No. 1, pp. e20211084. http://dx.doi.org/10.14488/BJOPM.2021.004.

Seuring, S. and Gold, S. (2012), "Conducting content-analysis based literature reviews in supply chain management", Supply Chain Management, Vol. 17, No. 5, pp. 544-55. http://dx.doi.org/10.1108/13598541211258609.

Seuring, S. and Müller, M. (2008), "From a literature review to a conceptual framework for sustainable supply chain management", Journal of Cleaner Production, Vol. 16, No. 15, pp. 1699-710. http://dx.doi.org/10.1016/j.jclepro.2008.04.020.

Seuring, S., Yawar, S.A., Land, A. et al. (2020), "The application of theory in literature reviews: illustrated with examples from supply chain management", International Journal of Operations \& Production Management, Vol. 41, No. 1, pp. 1-20. http://dx.doi.org/10.1108/IJOPM-04-2020-0247.

Shin, N., Park, S.H. and Park, S. (2019), "Partnership-Based Supply Chain Collaboration:Impact on Commitment, Innovation, and Firm Performance", Sustainability, Vol. 11, No. 449, pp. 1-19. http://dx.doi.org/10.3390/su11020449.

Silva, M.E. and Figueiredo, M.D. (2020), "Practicing sustainability for responsible business in supply chains", Journal of Cleaner Production, Vol. 251, pp. 119621. http://dx.doi.org/10.1016/j.jclepro.2019.119621.

Silva, M.E. and Nascimento, L.F. (2015), "Emphasizing social issues toward sustainable supply chain: a Brazilian perspective", Independent Journal of Management \& Production, Vol. 6, No. 2, pp. 478-94. http://dx.doi.org/10.14807/ijmp.v6i2.288.

Silva, M.E., Fritz, M.M.C. and Nunes, B. (2017), "Scanning insights on sustainability and supply chain management in Brazil", Journal of Operations and Supply Chain Management, Vol. 10, No. 1, pp. 33. http://dx.doi.org/10.12660/joscmv10n1p33-54.

Touboulic, A. and Walker, H. (2015a), "Love me, love me not: a nuanced view on collaboration in sustainable supply chains", Journal of Purchasing and Supply Management, Vol. 21, No. 3, pp. 178-91. http://dx.doi.org/10.1016/j.pursup.2015.05.001. 
Touboulic, A. and Walker, H. (2015b), "Theories in sustainable supply chain management: a structured literature review", International Journal of Physical Distribution \& Logistics Management, Vol. 45, No. 12, pp. 16-42. http://dx.doi.org/10.1108/IJPDLM-05-2013-0106.

Tranfield, D., Denyer, D. and Smart, P. (2003), "Towards a methodology for developing evidence-informed management knowledge by means of systematic review", British Journal of Management, Vol. 14, No. 3, pp. 207-22. http://dx.doi.org/10.1111/1467-8551.00375.

Tsai, W. and Ghoshal, S. (1998), "Social capital and value creation : the role of intrafirm networks", Academy of Management Journal, Vol. 41, No. 4, pp. 464-76.

Villena, V.H., Revilla, E. and Choi, T.Y. (2011), "The dark side of buyer-supplier relationships: a social capital perspective", Journal of Operations Management, Vol. 29, No. 6, pp. 561-76. http://dx.doi.org/10.1016/j.jom.2010.09.001.

Author contributions: Gustavo Dias - Conceptualization, Methodology, Data collection, Formal analysis, and Writing - Original Draft; Minelle Silva - Conceptualization, Writing - Review \& Editing, Visualization, Supervision. 


\section{APPENDIX: LIST OF THE PAPERS}

(01) Min, S. and Kim, S. K. (2008) ‘Developing Social Identity and Social Capital', Journal of Business. Vol. 29 No.1, pp. 283-304. [Theory; Three SCT dimensions; Economic]

(02) Lawson, B., Tyler, B. B. and Cousins, P. D. (2008) 'Antecedents and consequences of social capital on buyer performance improvement', Journal of Operations Management. Vol. 26 No. 3, pp. 446-460. [Survey; Structural and Relational; Economic]

(03) Autry, C. W. and Griffis, S. E. (2008) 'Supply Chain Capital: the Impact of Structural and Relational Linkages on Firm Execution and Innovation', Journal of Business Logistics. Vol. 29 No. 1, pp. 157-173. [Case; Structural and Relational; Economic]

(04) Bernardes, E. S. (2010) 'The effect of supply management on aspects of social capital and the impact on performance: a social network perspective.', Journal of Supply Chain Management. Vol. 46 No. 1, pp. 45-56. [Survey; Structural and Relational; Economic]

(05) Villena, V. H., Revilla, E. and Choi, T. Y. (2011) 'The dark side of buyer-supplier relationships: A social capital perspective', Journal of Operations Management. Vol. 29 No. 6, pp. 561-576. [Survey; Three SCT dimensions; Economic]

(06) Hitt, M. A. (2011) 'Relevance of strategic management theory and research for Supply chain management', Journal of Supply Chain Management. Vol. 47 No. 1, pp. 9-13. [Theory; Three SCT dimensions; Economic]

(07) Hammervoll, T. (2012) 'Honeymoons in supply chain relationships: The effects of financial capital, social capital and psychological commitment', International Journal of Logistics Management. Vol. 22 No. 2, pp. 264-279. [Theory; Relational Capital; Mix]

(08) Carey, S., Lawson, B. and Krause, D. R. (2011) 'Social capital configuration, legal bonds and performance in buyer-supplier relationships', Journal of Operations Management. Vol. 29 No. 4, pp. 277-288. [Survey; Three SCT dimensions; Economic]

(09) Cai, S., Yang, Z. and Jun, M. (2011) 'Cooperative norms, structural mechanisms, and supplier performance: Empirical evidence from Chinese manufacturers', Journal of Purchasing and Supply Management. Vol. 17 No. 1, pp. 1-10. [Survey; Three SCT dimensions; Economic]

(10) Wu, G. C., Ding, J. H. and Chen, P. S. (2012) 'The effects of GSCM drivers and institutional pressures on GSCM practices in Taiwan's textile and apparel industry', International Journal of Production Economics. Vol. 135 No. 2, pp. 618-636. [Survey; Three SCT dimensions; Environmental]

(11) Matthews, R. L. and Marzec, P. E. (2011) 'Social capital, a theory for operations management: a systematic review of the evidence', International Journal of Production Research. Vol. 50 No 24, pp. 7081-7099. [Review; Three SCT dimensions; Economic]

(12) Kim, K. K. et al. (2012) 'Knowledge complementarity and knowledge exchange in supply channel relationships', International Journal of Information Management. Vol. 32 No. 1, pp. 35-49. [Survey; Relational Capital; Economic]

(13) Cheng, T. C. E., Yip, F. K. and Yeung, A. C. L. (2012) 'Supply risk management via guanxi in the Chinese business context: The buyer's perspective', International Journal of Production Economics. Vol. 139 No. 1, pp. 3-13. [Survey; Relational Capital; Economic]

(14) Oke, A. and Prajogo, D. I. (2013) 'Strengthening the innovation chain: the role of internal innovation climate and strategic relationships with supply chain partners.', Journal of Supply Chain Management. Vol. 49 No.4, pp. 43-58. [Survey; Three SCT dimensions; Economic]

(15) Johnson, N., Elliott, D. and Drake, P. (2015) 'Exploring the role of social capital in facilitating supply chain resilience', Supply Chain Management: An International Journal. Vol. 20 No. 4, pp. 471-484. [Case; Three SCT dimensions; Economic]

(16) Roden, S. and Lawson, B. (2014) 'Developing social capital in buyer-supplier relationships: The contingent effect of relationship-specific adaptations', International Journal of Production Economics. Elsevier, Vol. 151, pp. 89-99. [Survey; Three SCT dimensions; Economic]

(17) Meehan, J. and Bryde, D. J. (2014) ‘Procuring sustainably in social housing: The role of social capital', Journal of Purchasing and Supply Management. Elsevier. Vol. 20 No. 2, pp. 74-81. [Survey; Three SCT dimensions; Environmental] 
(18) Li, Y., Ye, F. and Sheu, C. (2014) 'Social capital, information sharing and performance Evidence from China', International Journal of Operations \& Production Management. Vol. 34 No. 11, pp. 1440-1462. [Survey; Three SCT dimensions; Economic]

(19) Lee, H., Kim, M. S. and Kim, K. K. (2014) 'Interorganizational information systems visibility and supply chain performance', International Journal of Information Management. Vol. 34 No. 2, pp. 285-295. [Model; Relational Capital; Economic]

(20) Horn, P., Scheffler, P. and Schiele, H. (2014) 'Internal integration as a pre-condition for external integration in global sourcing: A social capital perspective', International Journal of Production Economics. Vol. 153, pp. 54-65. [Model; Three SCT dimensions; Economic]

(21) Hsu, C. C., Tan, K. C. and Laosirihongthong, T. (2014) 'Antecedents of SCM practices in ASEAN automotive industry: Corporate entrepreneurship, social capital, and resourcebased perspectives', International Journal of Logistics Management. Vol. 25 No. 2, pp. 334-357.

(22) Chen, P. C. and Hung, S. W. (2014) 'Collaborative green innovation in emerging countries: A social capital perspective', International Journal of Operations and Production Management. Vol. 34 No.3, pp. 347-363. [Model; Three SCT dimensions; Environmental]

(23) Wichmann, B. K., Carter, C. R. and Kaufmann, L. (2015) 'How to become central in an informal social network: An investigation of the antecedents to network centrality in an environmental SCM initiative', Journal of Business Logistics. Vol. 36 No. 1, pp. 102-119. [Survey; Relational Capital; Environmental]

(24) Whipple, J. M., Wiedmer, R. and Boyer, K. K. (2015) 'A dyadic investigation of collaborative competence, social capital, and performance in buyer - supplier relationships.', Journal of Supply Chain Management. Vol. 51 No. 2, pp. 3-21. [Survey; Three SCT dimensions; Economic]

(25) Mazzola, E., Bruccoleri, M. and Perrone, G. (2015) 'Supply chain of innovation and new product development', Journal of Purchasing and Supply Management. Vol. 21 No.4, pp. 273284. [Survey; Three SCT dimensions; Economic]

(26) Lee, S. Y. (2015) 'The effects of green supply chain management on the supplier's performance through social capital accumulation', Supply Chain Management. Vol. 20 No. 1, pp. 42-55. [Survey; Structural and Relational; Mix]

(27) Woo, C. et al. (2016) 'Suppliers' communication capability and external green integration for green and financial performance in Korean construction industry', Journal of Cleaner Production. Vol. 112, pp. 483-493. [Survey; Three SCT dimensions; Mix]

(28) Son, B., Kocabasoglu-hillmer, C. and Roden, S. (2016) 'A dyadic perspective on retailer - supplier relationships through the lens of social capital', International Journal of Production Economics. Vol. 178, pp. 120-131. [Survey; Three SCT dimensions; Economic]

(29) Kaufmann, L., Carter, C. R. and Rauer, J. (2016) 'The Coevolution of Relationship Dominant Logic and Supply Risk Mitigation Strategies', Journal of Business Logistics. Vol. 37 No. 2, pp. 87-106. [Grounded Theory; Three SCT dimensions; Economic]

(30) Jacobs, M. A., Yu, W. and Chavez, R. (2016) 'The effect of internal communication and employee satisfaction on supply chain integration', International Journal of Production Economics. Vol. 171, pp. 60-70. [Model; Three SCT dimensions; Economic]

(31) Hwang, Y. M. and Rho, J. J. (2014) 'Strategic value of RFID for inter-firm supply chain networks: An empirical study from a resource and social capital perspective', Information Development. Vol. 32 No.3, pp. 509-526. [Model; Three SCT dimensions; Economic]

(32) Gelderman, C. J., Semeijn, J. and Mertschuweit, P. P. (2016) 'The impact of social capital and technological uncertainty on strategic performance: The supplier perspective', Journal of Purchasing and Supply Management. Vol. 22, pp. 225-234. [Survey; Three SCT dimensions; Economic]

(33) Zhang, M., Guo, H. and Zhao, X. (2017) 'Effects of social capital on operational performance: impacts of servitisation', International Journal of Production Research. Vol. 55 No. 15, pp. 4304-4318. [Survey; Three SCT dimensions; Economic]

(34) Preston, D. S. et al. (2017) 'Generating Supplier Benefits through Buyer-Enabled Knowledge Enrichment: A Social Capital Perspective', Decision Sciences. Vol. 48 No. 2, pp. 248287. [Survey; Three SCT dimensions; Economic] 
(35) Kim, K. T., Lee, J. S. and Lee, S. Y. (2017) 'The effects of supply chain fairness and the buyer's power sources on the innovation performance of the supplier: a mediating role of social capital accumulation', Journal of Business and Industrial Marketing. Vol. 32 No. 7, pp. 987997. [Survey; Structural and Relational; Economic]

(36) Geng, R. et al. (2017) 'The role of Guanxi in green supply chain management in Asia's emerging economies: A conceptual framework', Industrial Marketing Management. Vol. 63, pp. 1-17. [Review; Three SCT dimensions; Environmental]

(37) Chu, S. H. et al. (2017) 'The impact of institutional pressures on green supply chain management and firm performance: Top management roles and social capital', Sustainability. Vol. 9 No. 5. [Model; Three SCT dimensions; Mix]

(38) Chowdhury, M., Jayaram, J. and Prajogo, D. (2017) 'The influence of socialisation and absorptive capacity on buyer's innovation performance', International Journal of Production Research. Vol. 55 No. 23, pp. 7022-7039. [Survey; Three SCT dimensions; Economic]

(39) $\mathrm{Wu}$, I. L. and Chiu, M. L. (2018) 'Examining supply chain collaboration with determinants and performance impact: Social capital, justice, and technology use perspectives', International Journal of Information Management. Vol. 39, pp. 5-19. [Survey; Three SCT dimensions; Economic]

(40) Peng, B., Tu, Y. and Wei, G. (2018) 'Governance of electronic waste recycling based on social capital embeddedness theory', Journal of Cleaner Production. Vol. 187, pp. 29-36. [Survey; Structural and Cognitive; Mix]

(41) Chakkol, M. et al. (2018) 'Social capital is not for sale: a supply network perspective on mergers and acquisitions', Supply Chain Management. Vol. 23 No. 5, pp. 377-395. [Case; Three SCT dimensions; Economic]

(42) Lu, H. E. et al. (2018) 'Exploring sustainable supply chain management: a social network perspective', Supply Chain Management: An International Journal. Vol. 23 No. 4, pp. $522-$ 541. [Review; Relational Capital; Mix]

(43) Lee, C.-H. and Ha, B.-C. (2018) 'The impact of buyer-supplier relationships' social capital on bi- directional information sharing in the supply chain', Journal of Business and Industrial Marketing. Vol. 33 No. 3, pp. 325-336. [Survey; Three SCT dimensions; Economic]

(44) Kilubi, I. and Rogers, H. (2018) 'Bridging the gap between supply chain risk management and strategic technology partnering capabilities: insights from social capital theory', Supply Chain Management: An International Journal. Vol. 23 No. 4, pp. 351-376. [Theory; Three SCT dimensions; Economic]

(45) Johnson, J. L. et al. (2018) 'Emerging Discourse Incubator: Cross-Sector Relations in Global Supply Chains: A Social Capital Perspective', Journal of Supply Chain Management. Vol. 54 No. 2, pp. 21-33. [Theory; Three SCT dimensions; TBL]

(46) Handoko, I., Bresnen, M. and Nugroho, Y. (2018) 'Knowledge exchange and social capital in supply chains.', International Journal of Operations \& Production Management. Vol. 38, pp. 90-108. [Case; Three SCT dimensions; Economic]

(47) Fan, Y. and Stevenson, M. (2018) 'Reading on and between the lines: risk identification in collaborative and adversarial buyer - supplier relationships', Supply Chain Management: An International Journal. Vol. 23 No. 4, pp. 351-376. [Case; Three SCT dimensions; Economic]

(48) Chen, M. et al. (2018) 'Top managers' managerial ties, supply chain integration, and firm performance in China: A social capital perspective', Industrial Marketing Management. Vol. 74, pp. 205-214. [Survey; Relational Capital; Economic]

(49) Ataseven, C., Nair, A. and Ferguson, M. (2018) 'An Examination of the Relationship between Intellectual Capital and Supply Chain Integration in Humanitarian Aid Organizations: A Survey-Based Investigation of Food Banks', Decision Sciences. Vol. 49 No.5, pp. 827-862. [Survey; Three SCT dimensions; Social]

(50) Zhu, Q. and Lai, K. hung (2019) 'Enhancing supply chain operations with extended corporate social responsibility practices by multinational enterprises: Social capital perspective from Chinese suppliers', International Journal of Production Economics. Vol. 213, pp. 1-12. [Survey; Relational Capital; Social] 
(51) Swierczek, A. (2019) 'Manufacturer structural embeddedness and the network rent: the intervening role of relational embeddedness in the triadic supply chains', Supply Chain Management. Vol. 24 No. 3, pp. 334-354. [Survey; Relational and Structural; Social]

(52) Shin, N., Park, S.H. and Park, S. (2019) 'Partnership-Based Supply Chain Collaboration:Impact on Commitment, Innovation, and Firm Performance', Sustainability. Vol. 11 No. 449, pp. 1-19. [Survey; Three SCT dimensions /Economic]

(53) Polyviou, M., Croxton, K. L. and Knemeyer, A. M. (2019) 'Resilience of medium-sized firms to supply chain disruptions: the role of internal social capital', International Journal of Operations and Production Management. Vol. 40 No. 1, pp. 68-91. [Case; Three SCT dimensions; Economic]

(54) Najjar, M. S., Dahabiyeh, L. and Nawayseh, M. (2019) 'Share if you care: The impact of information sharing and information quality on humanitarian supply chain performance - a social capital perspective', Information Development. Vol. 35 No. 3, pp. 467-481. [Survey; Three SCT dimensions; Social]

(55) Mora-Monge, C. et al. (2019) 'Trust, power and supply chain integration in Webenabled supply chains', Supply Chain Management. Vol. 24 No. 4, pp. 524-539. [Survey; Three SCT dimensions; Economic]

(56) Li, D. et al. (2019) 'Sharing economy-based service triads: Towards an integrated framework and a research agenda', Journal of Cleaner Production. Vol. 218, pp. 1031-1044. [Review; Three SCT dimensions; TBL] 